\title{
Escola Brasileira de Administração Pública da Fundação Getúlio Vargas (*)
}

\section{Belmiro Siqueira}

Dr. Rafael Xavier, DD. Diretor Executivo da Fundação. Exmos. Sts. Embaixadores e Representantes, outras autoridades. Dr. Benedicto Silva, operoso Diretor da Escola Brasileira de Administração Pública. Distintíssimos Professôres. Outros membros da mesa. Minhas Senhoras. Meus senhores. Prezadíssimos colegas e amigos.

No decorrer de nosso curso de Administração de Pessoal, tivemos ocasião de vos lembrar que, segundo pesquisas realizadas, o mais significativo para a felicidade humana não era alto salário ou alto cargo em si, era o indivíduo saber-se considerado, era o indivíduo saber-se merecedor de atenções. Chegamos mesmo a vos dizer que a primeira tragédia registada na Bíblia originouse, justamente, do fato de CAIM achar que não tinha sido considerado pelo Senhor JEovÁ: ficou magoado, aborrecido, e, interpelado pelo irmão, sua ira se ascendeu, chegando ao ponto de matá-lo.

Assim, com base científica, estribado na Psicologia Experimental, afirmamos que nada é mais importante para o bem-estar de cada um de nós do que sermos objeto de cuidados, alvo de atenções, merecedores de consideração. A partir desta afirmativa, todos os prezados ouvintes poderão aquilatar a satisfação que tivemos ao receber votos dos caros amigos, considerando-nos, elegendo-nos à posição de paraninfo da turma .

Muito obrigado! Muito obrigado pela atenção que nos deram. Amanhã, depois, daqui a anos, nós nos lembraremos com a saudade mais deleitosa e intranhável.

Chegamos ao término de quatro meses de treinamento intensivo. Vossa presença aqui, nesta solenidade, é a consagração do esfôrço despendido, é o coroamento dos resultados obtidos. Nas provas aplicadas e nos exames realizados na E.B.A.P., tivestes o mais pleno êxito. Voltareis agora, para as vcssas repartiçóes, para os vossos ambientes de trabalho e, lá, no "work testing", é que sentireis mais e mais o que significou êste período de treinamento, é lá que ouvireis mais e mais as palavras dos professôres e é lá que tereis a oportunidade de pôr em prática os princípios e normas que orientam as mais sadias gerências administrativas. É lá, no trabalho, com novas atitudes e mais

(*) Discurso proferido por ocasião da solenidade de entrega de Certificados aos alunos que concluiram o $1 .^{\circ}$ semestre dos Cursos Intensivos, realizada em 15 de julho de 1957, no Auditório do Ministério de Educação e Cultura. 
técnicos conceitcs instrumentais que tereis o ensejo de lutas e embates e de vitórias e derrotas para implantação de maior eficiência na vida profissional e, em conseqüência, na vida particular.

A que visavam os cursos intensivos que acabais de fazer?

Proporcionar treinamento, treinamento nos diversos setores da Administração Geral, aperfeiçoar, especializar, adaptar, readaptar e integrar milhares e milhares de servidores nos seus cargos e funções públicas.

Desperdício, baixo rendimento, atritos, insatisfação... são alguns dos característicos marcantes certas áreas de nossa Administração Pública.

O desprestígio dos serviços públiccs é a regra e a má-fama funcional é apanágio expressivo do funcicnário público.

Isso, porém, não perdurará indefinidamente. Vós mesmos sois mais alguns dos poucos que sabem que se impõem uma renovação de atitudes e uma revolução de idéias.

A Fundação Getúlio Vargas procurou desenvolver em vós não só essa nova atitude desejável mas, também, procurou vos vender um mundo de idéias pertinentes à ciência e à técnica da Administração.

Até onde a E.B.A.P. logrou êxito?

Nós confiamos em vós e não temos dúvida que, dia após dia, diuturnamente, pelos meses e ancs em fora, vossa preỏcupação constante será: mais eficiência no trabalho, mais eficiência até na vida particular.

Vasso esfôrço constante e contínuo - năo duvidaremos jamais - será no sentido de, em tudo, máxime na Administração Pública, fazer mais, fazer melhor, fazer em menor tempo, tazer com menor custo e, como coroamento disso, efetivar as mais proveitosas relações humanas.

Estamos seguras de que cada um de vós, além de estar se preocupando com eficiência máxima, cuidará, sempre, de estar pondo em prática o método das três posições, que tanto vos recomendanos e que é capaz de transformar a nossa vida, a vida de nossas repartiçóes e acelerar a marcha de desenvolvimento dêste país.

Primeiro - Importa que sempre estejanos fazendo alguma coisa, - de nenhuma forma podemos ou devemos apenas consumir, é indispensável que contìnuamente produzamos alguma coisa e produzamos bem.

Segundo - Importa que sempre estejamos aprendendo alguma coisa, adquirindo algum novo conhecimento, desenvolvendo alguma habilidade, dominando alguma nova técnica, valorizando-nos cạda vez mais: nos dias que correm, aquêle que não esta se esforçando para aprender sempre mais, não está apenas parado, está retrocedendo.

Terceiro - Importa que sempre estejamos ensinando alguma coisa, passando a terceiros aquilo que sabemos fazer ou já aprendemos - preparando outros profissionais em nosso campo de ação, longe de têrmos perniciosa concorrência. O que teremos é maior cooperação, mais forte colaboração e acentuado espírito de equipe e de solidariedade humana! 
Êste é um caminho infalível do sucesso pessoal: estar sempre fazendo alguma coisa, estar sempre aprendendo alguma coisa e estar sempre ensinando alguma coisa. Esste é um procedimento que vos recomendo.

Se nos perguntassem qual o principal fator para o progresso de nosso país, responderíamos - o fator humano. Todos os nossos grandes problemas têm suas soluções condicionadas ao fator humano. Urge que lutemcs desesperadamente neste sentido, no sentido de valorizar nosso potencial humano.

Em todos os setores da vida da nacionalidade, a questão é sempre a mesma: não há profissionais competentes, não há técnicos em número suficiente, a mão-de-obra disponível é precaríssima.

Poderíamos citar dezenas de repartições governamentais cujos recursos são polpudos, cujas instalações são primorosas e cujos regimentos e planos de trabalho são padrões admiráveis - mas não têm pessoal, falham e fracassam por causa do material humano.

Uma Alemanha arrebentada ontem, ressurge hoje. Uma Rússia que ontem não sabia fabricar trincos de fechadura, agora nos horroriza com seus engenhos bélicos. Os Estados Unidos, com alguns anos mais do que nós, andam quilômetros e quilômetros à nossa frente.

E por que êsse progresso?

E por que o nosso atraso?

Sobretudo por uma coisa - diferença de potencial humano, diferença de fôrça de trabalho, diferença de qualificações profissionais.

Formemos mais e mais profissionais competentes. Desenvclvamos sistemáticos programas de treinamento, de treinamento de chefes e de pessoal executivo, e, dentro em pouco, teremos todos os nossos grandes problemas satisfatòriamente equacionados.

Nosso grande ponto fraco é pessoal, é administração de pessoal, é administração de pessoal em todos os campos de nossas atividades.

E para solução dêste problemma, nenhum fator é mais preponderante que o treinamento - treinamento em todos os níveis, em todos os sentidos.

Gastemos milhões em treinamento e teremos bilhões em produtividade e bem-estar.

Nosso operário poderia fcrrar seis carros por semana. Mas êle só forra um. Por que? Porque lhe falta adequada atitude diante da profissão, adequada atitude diante da própria vida.

Nosso professor de Metemática poderia nos ensinar 100 problemas práticos, de nossa vida cotidiana. Mas, o que faz? Desenvolve em nós atitude de frustração, sensação de fracasso.

$\mathrm{E}$ os nussos seis anos de Inglês no Curso Secundário? Estudamos até literatura inglêsa e nos atropelamos diante do americano que, na rua, nos falou: - "Please, where is the post office?"

Necessitamos de mais pragmatismo! Necessitamos de mais objetividade! Jecessitamos de mais educação no sentido de melhor preparação para a vida e de mais treinamento, no sentido de melhor preparo para o trabalho. 
Não queremos dizer que tudo está mal e que nada se vem fazendo para melhorar a situação reinante.

Vossa presença aqui seria um desmentido de tal afirmativa.

A Fundação Getúlio Vargas, por exemplo, é um esfôrço significativo e rromissor no sentido de atenuar e sanar êste estado de coisas no que concerne

Administração Pública. A Fundação Getúlio Vargas é um esfôrço admirável de Simões Lopes e outros no sentido de mais eficiência, de pretender melhores serviços públicas.

E vós que podereis fazer?

Muito. Muito.

Cada um de vós se estiverdes vos esforçando por mais eficiência pessoal e por ocupar as três posições, muito já estareis fazendo.

Façamos como a avezinha que molhava as asas no riacho e sobrevoava o incêndio da floresta batendo-as. Interpelada pelo corvo, respondeu como PASTEUR: - "Não sei se estou fazendo muito ou pouco, só sei que estou fazendo tudo que posso."

Com êste esfôrço, tereis a sensação do dever cumprido, e, posso vas garantir, nenhuma alegria é mais perene que esta.

Lutai e esforçai-vos por mais eficiência pessoal. E, se nada conseguirdes, lembrai-vos de que o esfôrço é o que vale e o que se leva em conta à luz da eternidade! 